\title{
Seroprevalence of hepatitis c virus among population in Luxor Governorate, Egypt
}

\begin{abstract}
Background: Hepatitis C virus (HCV) is one of the hepatitis viruses that transmitted through blood or blood products. HCV has been implicated as a major reason of chronic liver disease and hepatocellular carcinoma worldwide.

Aim: To determine the seroprevalence of HCV antibodies among community in Luxor governorate, Egypt. Moreover to assess if there is any association with the population group, sex, age and other different risk factors.

Method: We randomly selected 745 blood samples; from males and females of different ages. Samples were collected from Luxor governorate, Egypt. Seras from all subjects were tested for hepatitis $\mathrm{C}$ virus antibodies using rapid test method and confirmed with the enzyme linked immunosorbent assay (ELISA) third generation.

Results: Our results show that $584(78.40 \%)$ of the community were males and most of them were aged between 31 and 50 years. Thirty two (5.48\%) from blood samples of males were anti-HCV seropositive and the highest prevalence of anti-HCV (7.22\%) of age groups from 41-50 years. One hundred and sixty one (21.60\%) from the community were female and most of them aged between $41-65$ years. Six (3.73\%) of female subjects tested positive for anti-HCV and the highest prevalence of anti-HCV (4.87\%) with age groups from 31-40 years. Four risk factors reflecting high mechanisms of HCV transmission have been associated with $\mathrm{HCV}$ infection including residing in rural areas, no education, blood transfusion and dental treatment. Exposures to surgery, history of schistosomiasis show low association with Anti-HCV. Among the community exposures, including blood donation and alcohol consumption but these associations are not important.
\end{abstract}

Conclusion: This study has been conducted to determine the prevalence rate of anti-HCV among community in Luxor governorate, Egypt. It is our hope that the data genarated will be an addition to the existing pool of HCV data available in the Egypt.

Keywords: Hepatitis C Virus, Antibody, Prevalence, Luxor, Risk factors
Volume 5 Issue 2 - 2017

\section{El-Adly AM, Wardany AA}

Botany \& Microbiology Department, Faculty of Science, AlAzhar University, Egypt

Correspondence: El-Adly AM, Botany \& Microbiology Department, Faculty of Science, Al-Azhar University, 71524 Assiut, Egypt, Tel 0 I I 47787828, Email eladly8 @ @yahoo.com

Received: January II, 2017 | Published: February 09, 2017
Abbreviations: HCV, Hepatitis C Virus; EDHS, Egyptian Demographic Health Survey; EHIS, Egypt Health Issues Survey; PAT, Parenteral Antischistosomiasis Therapy; ELISA, Enzyme Linked Immunosorbent Assay

\section{Introduction}

Hepatitis C virus (HCV), was first identified in $1989,{ }^{1}$ it is a spherical, enveloped, single stranded RNA virus belongs to Flaviviridae family and having humans and chimpanzees as the only species vulnerable to its infection. ${ }^{2,3}$ There are at least 7 genotypes and more than 67 subtypes of $\mathrm{HCV}$ were identified, the different HCV genotypes have different distribution. ${ }^{4} \mathrm{HCV}$ Genotype 4 is the predominant genotype being isolated from up to $91 \%$ of $\mathrm{HCV}$-infected persons in Egypt. ${ }^{5}$

$\mathrm{HCV}$ is a global public health problem, there are about 130 to 150 million people suffer from chronic $\mathrm{HCV}^{6}{ }^{6}$ The highest prevalence of $\mathrm{HCV}$ in the world occurs in Egypt with estimates higher than $10 \%$ among the general population. There are approximately, 3.7 million persons in Egypt have chronic HCV infection in 2015. ${ }^{6,7}$

The high prevalence of HCV is not the only problem, but the high incidence of $\mathrm{HCV}$ is another important issue which reflects the new HCV infections that occurs annually, where about 160,000 to 500,000 new HCV infections occur annually. ${ }^{8,9}$

$\mathrm{HCV}$ is a blood borne virus and absent from most body fluids except those contain blood. There are many risk factors contribute for the bulk of HCV transmission worldwide which are as follows: blood transfusions from unscreened donors, unsafe therapeutic injections, reuse of contaminated medical equipment, injection drug use and other healthcare related procedures..$^{10}$ In Developed countries have accumulated evidence that the predominant source of new HCV infections within their borders over the past few decades is injection drug use. Most developing countries, unsafe therapeutic injections and transfusions are likely to be the major modes of transmission, especially in countries where age-specific seroprevalence rates suggest ongoing increased risk of HCV infection. ${ }^{11}$

Contaminated injection equipment appears to be the major risk factor for $\mathrm{HCV}$ transmission in several countries. ${ }^{12}$ Catching $\mathrm{HCV}$ infection after the age of 40 may be associated with a more rapid progression of liver injury, as well as male gender. ${ }^{13}$ Children appear to have a lower risk of disease progression. ${ }^{14}$ Alcohol consumption increases HCV replication, enhances the progression of chronic HCV, and accelerates liver injury. ${ }^{15}$ Treatment of schistosomiasis patients by using parenteral antischistosomal therapy (PAT) campaigns is believed to be the major historic cause for increasing the prevalence of $\mathrm{HCV}$ in Egypt. ${ }^{16}$

Acute $\mathrm{HCV}$ infection is often difficult to detect given the stigmatization of risk groups and the generally asymptomatic nature of early infection. ${ }^{17} \mathrm{HCV}$ is not transmitted through casual contact such as sharing food or drinks with an infected person, kissing, and hugging. Also, it is not transmitted through breast milk. ${ }^{6}$ 
Our study is undertaken to know the current prevalence of anti$\mathrm{HCV}$ antibodies and risk factors related to anti-HCV antibodies in population of Luxor region of Egypt, as primary prevention of $\mathrm{HCV}$ infection is to check transmission of virus unknowingly by apparently healthy individuals who are asymptomatic.

\section{Materials and methods}

\section{Study area and data collection}

This study has been conducted from January through October 2016. The study has been carried out in Luxor governorate, Egypt. The population were males and females over 20 years old. They were randomly selected. Consent forms were prepared and approval of all subjects included in the study were obtained before blood was taken. In addition to the blood samples, all individual were interviewed and a questionnaire was filled to obtain information on age, place of living, education and other health care history. A total of seven hundred and forty five blood samples were collected for the study.

\section{Collection and processing of blood samples}

Blood samples were collected from each subject by vene-puncture of the cubital veins. The site was cleaned thoroughly using $70 \%$ isopropyl alcohol in water and $1 \%$ iodine for one minute and allowed to dry. Taking precautions to avoid contamination of the site, about 3 milliliters of blood was collected using a sterile syringe and needle and dispensed into clean plastic. The blood samples were centrifuged at $4000 \mathrm{rpm}$ for 10 minutes, and the serum obtained was stored at $-20^{\circ} \mathrm{C}$

All serum samples were transported to the virology laboratory of botany and microbiology department, Al-Azhar university, Assiut branch; where all the processing has been carried out.

\section{Serum Markers for HCV infection}

Anti-HCV is studied using third-generation ELISA tests (Ortho Diagnostics, Raritan, NJ, USA; and Abbott Diagnostics, North Chicago, IL, USA). Results are read using EL x 800 universal microplate reader, (Biotek Instruments Inc.). All positive samples were retested using the same method (double ELISA).

\section{Data analysis}

Data were analyzed using the SPSS version 16. Qualitative variables are described as numbers and percentages. Chi square or Fisher's exact test is used for comparison between groups; as appropriate. Odds ratios and their $95 \%$ confidence intervals were calculated. A p value $\leq 0.05$ is considered statistically significant.

\section{Results}

A total of 745 blood donors were included in the study. Their ages ranged from $20-65$ years old. Out of the 745 population tested for anti-HCV, $584(78.40 \%)$ are males whereas 161 (21.60\%) are females. More than sixty six percent $(66.16 \%)$ of the subjects are aged $31-50$ years, while those aged $\leq 30$ and $\geq 51$ years are comparatively few $(17.32 \%$ and $16.52 \%$ respectively) (Table1). These observed differences are high statistically significant.

\section{Gender specific prevalence of anti-HCV antibodies}

Out of the 745 serum samples, 38 tested positive, implying an overall prevalence of $5.10 \%$. Thirty two $(5.48 \%)$ of the 584 male subjects tested positive while $6(3.73 \%)$ of the 161 female subjects tested positive (Table 2). This gender related prevalence of anti-HCV antibodies are high statistically significant $\left(\mathrm{p}=0.000^{* *}\right)$. Age with gender specific prevalence of anti-HCV antibodies.
The seropositive cases related to age and genders are showed in Table 3. In males age groups 41-50 years have the highest prevalence of anti-HCV $13(7.22 \%)$, followed by age-groups 51-65 years with $5(6.10 \%)$ prevalence, while age-groups from $20-30$ and 31 40 years show lowest prevalence of anti-HCV $(2.60 \%$ and $5.31 \%$ respectively). In females predominant cases are in age groups 51-65 years with $2(4.87 \%)$ followed by age-groups 41-50 years with 3 (4.10\%) prevalence, while age-groups from $20-30$ and $31-40$ years show lowest prevalence of anti-HCV ( $0 \%$ and $3.03 \%$ respectively). These observed differences are not statistically significant.

Many healthcare exposures are associated with anti-HCV in the gender-adjusted analysis, including residence, education, surgery, blood transfusion and donation, alcohol consumption and history of schistosomiasis (Table 4 \& Figure 1). The strongest of these associations is for community residing in rural versus urban areas 31 of $542(5.72 \%)$ versus 7 of $203(3.45 \%)$ respectively with none statistically significant $(\mathrm{P}=0.202)$. History of blood transfusion is reported in $88(11.81 \%)$ community. Anti-HCV is more common in those who have received a blood transfusion than in those who have not received the same: $5(5.68 \%)$ and $33(5.02 \%)$, respectively with high statistically significant $\left(\mathrm{P}=0.000^{* *}\right)$. Dental treatment are associated with anti-HCV status among those $25(5.80 \%)$ compared with 13 $(4.14 \%)$ no dental treatment with non statistically significant $(\mathrm{P}=$ 321). Education shows association with Anti-HCV and more common in those who have no education than University attendance 72 (5.61 $\%)$ and $6(3.82 \%)$ respectively with high statistically significant $\left(\mathrm{P}=0.000^{* *}\right)$. Exposures to surgery, history of schistosomiasis show low association with Anti-HCV. Surgery related prevalence of anti$\mathrm{HCV}$ antibodies are high statistically significant $\left(\mathrm{P}=0.000^{* *}\right)$, while observed differences of history of schistosomiasis are not statistically significant $(\mathrm{P}=251)$. Among the community exposures, including blood donation and alcohol consumption but these association are not important (Table 4 \& Figure 2).

Table I Age and gender distribution of population in Luxor, Egypt

\begin{tabular}{|c|c|c|c|c|c|}
\hline \multirow{2}{*}{$\begin{array}{l}\text { Age ( } \\
\text { Years) }\end{array}$} & \multicolumn{2}{|l|}{ Gender } & \multirow{2}{*}{ Total, n (\%) } & \multicolumn{2}{|c|}{ Significance } \\
\hline & Male, n (\%) & Female, n (\%) & & $\chi_{2}$ & p value \\
\hline $20-30$ & $115(19.70 \%)$ & $14(8.70 \%)$ & $129(17.32 \%)$ & & \\
\hline $31-40$ & $207(35.44 \%)$ & $33(20.50 \%)$ & $240(32.21 \%)$ & & \\
\hline $41-50$ & $180(30.82 \%)$ & $73(45.34 \%)$ & $253(33.95 \%)$ & 35.38 & $>0.000 * *$ \\
\hline $51-65$ & $82(\mid 4.04 \%)$ & $4 \mathrm{I}(25.46 \%)$ & $123(16.52 \%)$ & & \\
\hline Total, n (\%) & $584(100 \%)$ & $161(100 \%)$ & $745(100 \%)$ & & \\
\hline
\end{tabular}

**high significant

Table 2 Gender related Prevalence of Anti-HCV antibodies

\begin{tabular}{llllll}
\hline Gender & Anti- HCV & & \multirow{2}{*}{ Total, n (\%) } & \multicolumn{2}{c}{ Significance } \\
& Positive, n (\%) & Negative, n (\%) & & p value \\
\hline Male & $32(5.48 \%)$ & $552(94.52 \%)$ & $584(100 \%)$ & \\
Female & $6(3.73 \%)$ & $155(96.27 \%)$ & $161(100 \%)$ & 14.55 & $0.000 * *$ \\
Total, n (\%) & $38(5.10 \%)$ & $707(94.90 \%)$ & $745(100 \%)$ & & \\
\hline
\end{tabular}

** high significant

Table 3 Gender and age specific Prevalence of Anti-HCV antibodies

\begin{tabular}{llllll}
\hline Age & \multicolumn{2}{l}{ Anti- HCV Positive, n (\%) } & Total, n (\%) & \multicolumn{2}{l}{ Significance } \\
& Male & Female & & p value \\
\hline $20-30$ & $3(2.60 \%)$ & $0(0 \%)$ & $3(2.32 \%)$ & & \\
$31-40$ & $11(5.31 \%)$ & I $(3.03 \%)$ & $12(5.00 \%)$ & & \\
$41-50$ & $13(7.22 \%)$ & $3(4.10 \%)$ & $16(6.32 \%)$ & 2.03 & 0.566 n.s. \\
$51-65$ & $5(6.10 \%)$ & $2(4.87 \%)$ & $7(5.70 \%)$ & & \\
Total, n (\%) & $32(5.48 \%)$ & $6(3.73 \%)$ & $38(5.10 \%)$ & & \\
\hline
\end{tabular}

n.s. $=$ non significant 
Table 4 Risk factors related Prevalence of anti-HCVantibdies among population in Luxor governorate, Egypt.

\begin{tabular}{|c|c|c|c|c|c|c|c|c|}
\hline \multirow{2}{*}{ Risk factors } & \multicolumn{3}{|c|}{ Participants, n (\%) } & \multicolumn{3}{|c|}{ Anti- HCV Positive, n (\%) } & \multirow{2}{*}{$\chi^{2}$} & \multirow{2}{*}{$p$ value } \\
\hline & Male & Female & Total & Male & Female & Total & & \\
\hline \multicolumn{9}{|l|}{ Residence } \\
\hline Rural & $416(7 \mid .23 \%)$ & $126(78.26 \%)$ & $542(72.75 \%)$ & $26(6.25 \%)$ & $5(3.96 \%)$ & $3 \mathrm{I}(5.72 \%)$ & \multirow{2}{*}{\multicolumn{2}{|c|}{-4.6230 .202 n.s. }} \\
\hline Urban & $168(28.77 \%)$ & $35(21.74 \%)$ & $203(27.25 \%)$ & $6(3.57 \%)$ & $\mathrm{I}(2.85 \%)$ & $7(3.45 \%)$ & & \\
\hline \multicolumn{9}{|l|}{ Education } \\
\hline $\begin{array}{l}\text { University } \\
\text { Attendance }\end{array}$ & I 48 (25.34 \%) & $9(5.60 \%)$ & I 57 (2।.08\%) & $6(4.05 \%)$ & $0(0 \%)$ & $6(3.82 \%)$ & \multirow{3}{*}{\multicolumn{2}{|c|}{$298.30 .000 * *$}} \\
\hline School Attendance & $76(|3.0| \%)$ & $31(19.25 \%)$ & $107(14.36 \%)$ & $4(5.26 \%)$ & I (3.22 \%) & $5(5.15 \%)$ & & \\
\hline No education & $360(61.65 \%)$ & $12 \mathrm{I}(75.15 \%)$ & $48 I(64.56 \%)$ & $22(6.11 \%)$ & $5(4.13 \%)$ & $27(5.61 \%)$ & & \\
\hline \multicolumn{9}{|c|}{ History of Blood donation } \\
\hline Yes & $47(8.05 \%)$ & $0(0 \%)$ & 47 (6.3। \%) & $0(0 \%)$ & $0(0 \%)$ & $0(0 \%)$ & \multirow{2}{*}{\multicolumn{2}{|c|}{$-210.10 .000^{* *}$}} \\
\hline No & 537 (9I.95 \%) & $161(100 \%)$ & $698(93.69 \%)$ & $32(5.95 \%)$ & $6(3.73 \%)$ & $38(5.44 \%)$ & & \\
\hline \multicolumn{9}{|c|}{ History of Blood Transfusion } \\
\hline Yes & $39(6.68 \%)$ & $49(30.43 \%)$ & $88(1 \mathrm{I} .81 \%)$ & $3(7.69 \%)$ & $2(4.08 \%)$ & $5(5.68 \%)$ & \multirow{2}{*}{\multicolumn{2}{|c|}{$-70.890 .000^{* *}$}} \\
\hline No & $545(93.32 \%)$ & $112(69.57 \%)$ & $657(88.19 \%)$ & $29(5.32 \%)$ & $4(3.57 \%)$ & $33(5.02 \%)$ & & \\
\hline \multicolumn{9}{|l|}{ Dental Treatment } \\
\hline Yes & $329(56.34 \%)$ & $102(63.35 \%)$ & $431(57.85 \%)$ & $21(6.38 \%)$ & $4(3.92 \%)$ & $25(5.80 \%)$ & \multirow{2}{*}{\multicolumn{2}{|c|}{$-3.4950 .32 \mathrm{In} . \mathrm{s}$}} \\
\hline No & $255(43.66 \%)$ & $59(36.65 \%)$ & $314(42.15 \%)$ & II (4.89\%) & $2(3.39 \%)$ & $13(4.14 \%)$ & & \\
\hline \multicolumn{9}{|l|}{ Surgery } \\
\hline Yes & $83(14.2 \mid \%)$ & $67(41.61 \%)$ & $150(20.13 \%)$ & $4(4.82 \%)$ & $3(4.48 \%)$ & $7(4.66 \%)$ & \multirow{2}{*}{\multicolumn{2}{|c|}{$-63.620 .000 * *$}} \\
\hline No & $50 I(85.79 \%)$ & $94(58.39 \%)$ & $595(79.87 \%)$ & $28(5.58 \%)$ & $3(3.19 \%)$ & $31(5.21 \%)$ & & \\
\hline \multicolumn{9}{|c|}{ Alcohol Consumption } \\
\hline Yes & $6(1.03 \%)$ & $0(0 \%)$ & $6(0.81 \%)$ & $0(0 \%)$ & $0(0 \%)$ & $0(0 \%)$ & \multirow{2}{*}{-2.06} & \\
\hline No & $578(98.97 \%)$ & 161 (100\%) & $739(99.19 \%)$ & $32(5.54 \%)$ & $6(3.73 \%)$ & $38(5.14 \%)$ & & 0.560n.s \\
\hline \multicolumn{9}{|c|}{ History of Schistosomiasis } \\
\hline Yes & $21(3.60 \%)$ & I (0.62 \%) & $22(2.95 \%)$ & $\mathrm{I}(4.76 \%)$ & $0(0 \%)$ & I (4.55\%) & \multirow{2}{*}{-4.103} & \\
\hline No & $563(96.40 \%)$ & $160(99.38 \%)$ & $723(97.05 \%)$ & $3 I(5.5 \mathrm{I} \%)$ & $6(3.75 \%)$ & 37 (5.12\%) & & 30.251 \\
\hline
\end{tabular}

n.s.= non significant

**high significant

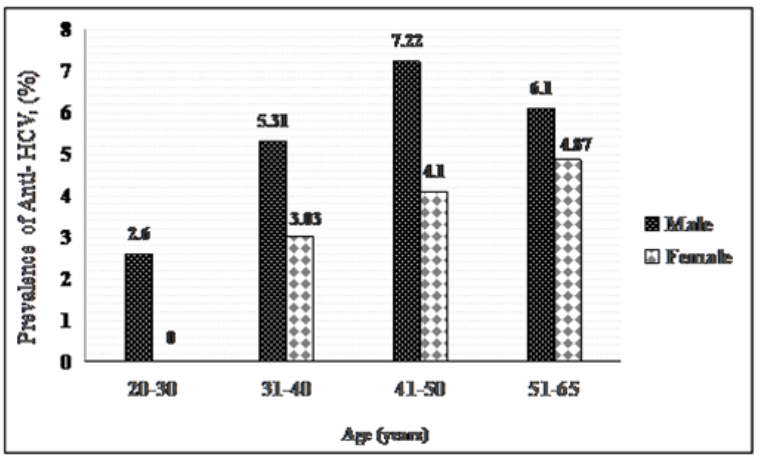

Figure I Gender and age specific Prevalence of Anti-HCV antibodies.

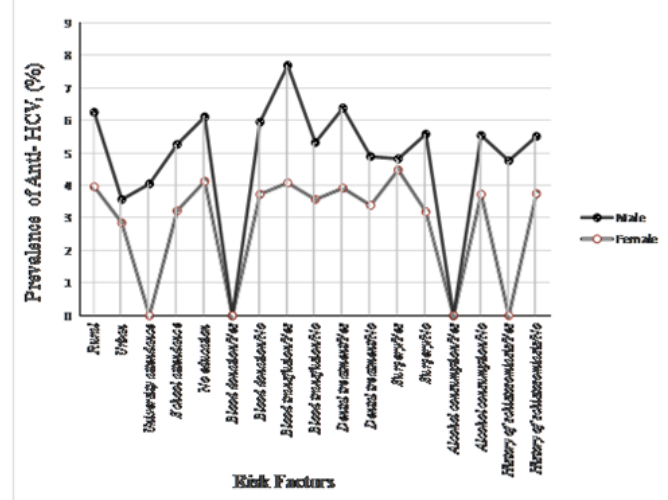

Figure 2 Risk factors related prevalence of anti-HCV antibodies.

\section{Discussion}

Egypt has the highest prevalence of $\mathrm{HCV}$ in the world, with more than $20 \%$ positive for $\mathrm{HCV}$ among blood screening and testing for the Egyptian blood donors. ${ }^{18}$ In 2008, Egypt Demographic and Health Survey (EDHS) using a national representative sample estimated the prevalence of $\mathrm{HCV}$ to be $14.7 \%$ among Egyptian between $15-59$ years of age by using $\mathrm{HCV}$ antibody test, which means that those people have been exposed to HCV. ${ }^{19}$ In 2015, Egypt Health Issues Survey (EHIS) using a nationally representative sample reported that $10 \%$ of Egyptians between 15-59 years of age have been infected with $\mathrm{HCV}$ infection, while $7 \%$ are chronic active hepatitis $\mathrm{C}$ patients. ${ }^{20}$

This study is performed in Luxor governorates of Egypt, where most of population live in rural regions. The present study documents small prevalence of $\mathrm{HCV}$ infection $(5.10 \%)$ in the study area as compared with other region in Egypt. Our results confirm findings in previous studies estimate 9\% prevalence in Upper Egypt as compared $24 \%$ prevalence in the Nile Delta. ${ }^{21,22}$

Among 745 samples tested, 584 (78.40\%) are males and remaining $161(21.60 \%)$ are females. The seroprevalence is higher among male $32(5.48 \%)$ as compared to female $6(3.73 \%)$, these results agree with EHIS 2015, estimate that the prevalence of HCV among males are more than females, and to findings of Vallab Ganesh Bharadwaj et al 2014., who also report higher prevalence of HCV in male $(0.7 \%)$ as compared to female $(0.66 \%){ }^{23}$ This male preponderance is explained by high exposure level pertaining to various risk factors of $\mathrm{HCV}$ transmission due to their lifestyle. These findings are not consistent with other studies where prevalence of anti-HCV antibody is higher among female as compared to male..$^{24,25}$ 
Current study estimats that, the seroprevalence of HCV among older age groups is much higher than the younger ones. The seropositive cases in current study remain higher in 41-50 years followed by 5165 years in males whereas in females predominant cases are in 5165 years followed by 41-50 years. Various other studies have also demonstrated high seroprevalence of anti-HCV antibody among adult population. ${ }^{23,26,27}$

In this study, four risk factors reflecting direct mechanisms of HCV transmission have been associated with HCV infection: Residence, education, blood transfusion and Dental treatment. Mohlman et al. ${ }^{28}$ report that community who born after 1980 have modest to low exposure to risk factors such as PAT, blood transfusion and blood donation. ${ }^{28}$ However, the association between aging populations and increased healthcare utilization. ${ }^{19}$ which in turn increase the risk for $\mathrm{HCV}$ transmission, and the high $\mathrm{HCV}$ positivity prevalence among individuals born before 1960 suggest that the latter cohorts may substantially contribute to the ongoing HCV transmission in Egypt. ${ }^{29}$

In our study, prevalence of anti-HCV is higher among community residing in rural versus urban areas $(5.72 \%$ vs. $3.45 \%$ respectively). This pattern of high anti-HCV prevalence in rural areas is similar to multiple studies conducted in rural areas of Delta governorates which show a prevalence ranging from 14.4 to $18.5 \% .^{21,30-32}$

Also, we documente that a low level of education is associated with a higher seroprevalence of HCV infection, it is found that it is higher in illiterate people $(5.61 \%)$ while it is much lower among people who have completed secondary education and higher education $(5.15 \%$ and $3.82 \%$ respectively). These findings agree with what El-Zanaty \& Way, 2009, report about the relation between educational level and HCV prevalence, it is found that it is higher in illiterate people $(14.5 \%)$ while it is much lower among people who have completed secondary education and higher (4.1\%). ${ }^{19}$

In a developed country, the risk factor of transmission through blood transfusion has greatly diminished with the introduction of effective screening. However, blood transfusion remains an important past and a potential current risk for $\mathrm{HCV}$ transmission in developing countries, where anti-HCV screening is limited by technical and financial factors. ${ }^{11}$ In our study, we find that seropositive cases of Anti-HCV are more common in those who have received a blood transfusion than in those who have not $(5.68 \%$ and $5.02 \%$ respectively). These results agree with Somaia et al. ${ }^{33}$ report that anti-HCV antibody positive patients received blood transfusion more frequently than $\mathrm{HCV}$ antibody-negative patient. ${ }^{33}$

In the present study, we demonstrate that the seropositive cases of anti-HCV remain highest $5.80 \%$ in people who underwent dental treatment as compared with $4.14 \%$ in people who did not undergo dental treatment. Various other studies report that, there is evidence of ongoing HCV incidence at dental and medical facilities. ${ }^{34,35}$ Although most studies have not found dental procedures to be a risk for $\mathrm{HCV}$ in Egypt or elsewhere. ${ }^{36,37}$

In our finding exposures to surgery and history of schistosomiasis show low association with Anti-HCV, while the community exposures to blood donation and alcohol consumption do not show any association with Anti-HCV. Mohlman et al. ${ }^{28}$ reported that not a statistically significant association between $\mathrm{HCV}$ positivity and blood donation. ${ }^{28}$ However, many other studies reported that, there is relation between these risk factors and increasing prevalence of antiHCV. ${ }^{19,34,38,39}$

\section{Conclusion}

The current study provides information on anti-HCV prevalence in the general population from Luxor governorate, Upper Egypt. The anti-HCV prevalence in the community is $5.10 \%$ and is higher among male than female subjects. Prevalence increases with age, and there is a sharp increase after 30 years of age. Other relatively common exposures included rate of education, blood transfusion, residence and dental treatment. HCV transmission in Egypt has reached diverse population groups including those who are not conventionally identified to be at risk of infection.

\section{Recommendations}

a. HCV prevention in Egypt must be a national priority.

b. Scientific research needs to be expanded to measure current $\mathrm{HCV}$ incidence rate and identify precisely the modes of $\mathrm{HCV}$ transmission in medical care, community, and house-hold settings.

c. Blood screening should take place carefully to reduce the number of transfusion.

d. Patient infected with HCV needs to be counseled to reduce the risk of $\mathrm{HCV}$ transmission to other persons.

\section{Acknowledgments}

None.

\section{Conflicts of interest}

None.

\section{References}

1. Choo QL, Kuo G, Weiner AJ, et al. Isolation of a cDNA clone derived from a blood-borne non-A, non-B viral hepatitis genome. Science. 1989;244(4902):359-362.

2. Sharma SD. Hepatitis $C$ virus: molecular biology \& current therapeutic options. Indian J Med Res. 2010;131:17-34.

3. Pennap GR, Yakubu A, Oyige O, et al. Prevalence of hepatitis B and C virus infection among people of a local community in Keffi, Nigeria. African Journal of Microbiology Research. 2010;4(4):274-278.

4. Smith DB, Bukh J, Kuiken C, et al. Expanded classification of hepatitis $\mathrm{C}$ virus into 7 genotypes and 67 subtypes: updated criteria and genotype assignment web resource. Hepatology. 2014;59(1):318-327.

5. Ray SC, Arthur RR, Carella A, et al. Genetic epidemiology of HCV throughout Egypt. J Infect Dis. 2000;182(3):698-707.

6. World Health Organization. Hepatitis C. Fact sheet, Geneva, Switzerland. 2015

7. Mastoi AA, Devrajani BR, Shah SZ, et al. Metabolic investigations in patients with hepatitis B and C. World $J$ Gastroenterol. 2010;16(5):603-607.

8. Miller FD, Abu-Raddad LJ. Evidence of intense ongoing endemic transmission of hepatitis C virus in Egypt. Proc Natl Acad Sci USA. 2010;107(33):14757-14762.

9. Breban R, Riou J, Fontanet A. Interhuman transmissibility of Middle East respiratory syndrome coronavirus: estimation of pandemic risk. Lancet. 2013;382(9893):694-699.

10. Sharma S, Carballo M, Feld JJ, et al. Immigration and viral hepatitis. $J$ Hepatol. 2015;63(2):515-522.

11. Wasley A, Alter M. Epidemiology of hepatitis C: geographic differences and temporal trends. Semin Liver Dis. 2000;20(1):1-16.

12. Shepard CW, Finelli L, Alter MJ. Global epidemiology of hepatitis C virus infection. Lancet Infect Dis. 2005;5(9):558-567. 
13. Svirtlih N, Jevtovic D, Simonovic J, et al. Older age at the time of liver biopsy is the important risk factor for advanced fibrosis in patients with chronic hepatitis C. Hepatogastroenterology. 2007;54(80):2324-2327.

14. Pawlowska M, Domagalski K, Pniewska A, et al. What's new in hepatitis $\mathrm{C}$ virus infections in children? World $J$ Gastroenterol. 2015;21(38):10783-10789.

15. Gitto S, Micco L, Conti F, et al. Alcohol and viral hepatitis: A minireview. Dig Liver Dis. 2009;41(1):67-70.

16. Frank C, Mohamed MK, Strickland GT, et al. The role of parenteral antischistosomal therapy in the spread of hepatitis C virus in Egypt. Lancet. 2000355(9207):887-891.

17. Hullegie SJ, Arends JE, Rijnders BJ, et al. Current knowledge and future perspectives on acute hepatitis C infection. Clin Microbiol Infect. 2015;21(8):797.

18. WHO. GAR-WHO Hepatitis C. Fact sheet, Geneva, Switzerland. 2016

19. El-Zanaty F, Way A. Egypt. Demographic Health Survey 2008 (EDHS 2008). Cairo: Ministry of Health and Population, National Population Council. India. 2009.

20. Ministry of Health and Population. El-Zanaty and Associates [Egypt], ICF International. Egypt Health Issues Survey 2015, Maryland, USA. 2015 .

21. Abdel-Aziz F, Habib M, Mohamed MK, et al. Hepatitis C virus (HCV) infection in a community in the Nile Delta: population description and HCV prevalence. Hepatology. 2000;32(1):111-115.

22. Mohamed MK, Abdel-Hamid M, Mikhail NN, et al. Intrafamilial transmission of hepatitis C in Egypt. Hepatology. 2005;42(3):683-687.

23. Bharadwaj BV, Vazhavandal G, Uma A, et al. Seroprevalence of Hepatitis C Virus Infection among Patients attending a rural teaching hospital in South India: A Three Year Study. Int J Curr Microbiol App Sci. 2014;3(2):123-127.

24. Ayele AG, Gebre Selassie S. Prevalence and risk factors of hepatitis $\mathrm{B}$ and hepatitis $\mathrm{C}$ virus infections among patients with chronic liver diseases in public hospitals in Addis Adaba, Ethiopia. ISRN Tropical Medicine. 2013(2013):1-7.

25. Ramarokoto CE, Rakotomanana F, Ratsitorahina M, et al. Seroprevalence of hepatitis $\mathrm{C}$ and associated risk factors in urban areas of Antananarivo, Madagascar. BMC Infect Dis. 2008;8:25.

26. Verma R, Behera BK, Jain RB, et al. Hepatitis C: A silent threat to community of Haryana, India: A community based study. Australas Med J. 2014;7(1):11-16.
27. Siddiqui FA, Akhtar K, Sherwani RK, et al. Prevalence of Hepatitis C virus in Aligarh: A seven year experience. Indian J Community Med. 2009;34(3):264-265.

28. Mohlman MK, Saleh DA, Ezzat S, et al. Viral transmission risk factors in an Egyptian population with high hepatitis C prevalence. BMC Public Health. 2015;15:1030.

29. Breban R, Arafa N, Leroy S, et al. Effect of preventative and curative interventions on hepatitis C virus transmission in Egypt (ANRS 1211): a modeling study. Lancet Glob Health. 2014;2(9):e541-549.

30. Stoszek SK, Abdel-Hamid M, Narooz S, et al. Prevalence of and risk factors for hepatitis $\mathrm{C}$ in rural pregnant Egyptian women. Trans $R$ Soc Trop Med Hyg. 2006;100(2):102-107.

31. El Gohary A, Hassan A, Nooman Z, et al. High prevalence of hepatitis $\mathrm{C}$ virus among urban and rural population groups in Egypt. Acta Trop. 1995;59(2):155-161.

32. Badr RS, Korah TE, Tawfeek AR, et al. A study on how patients catch hepatitis C virus. Menoufia Medical Journal. 2016;29(2):215-221.

33. Mousa SM, El-Ghamrawy MK, Gouda H, et al. Prevalence of Hepatitis $\mathrm{C}$ among Egyptian Children with Sickle Cell Disease and the Role of IL28b Gene Polymorphisms in Spontaneous Viral Clearance. Mediterr $J$ Hematol Infect Dis. 2016;8(1):e201600.

34. Kalil KA, Farghally HS, Hassanein KM, et al. Hepatitis C virus infection among paediatric patients attending University of Assiut Hospital, Egypt. East Mediterr Health J. 2010;16(4):356-361.

35. Barakat $\mathrm{SH}$, El-Bashir N. Hepatitis $\mathrm{C}$ virus infection among healthy Egyptian children: prevalence and risk factors. $J$ Viral Hepat. 201118(11):779-784.

36. Habib M, Mohamed MK, Abdel-Aziz F, et al. Hepatitis C virus infection in a community in the Nile Delta: risk factors for seropositivity. Hepatology. 2001;33(1):248-253.

37. Enomoto A, Yoshino S, Hasegawa H, et al. Phylogenetic investigation for the risk of hepatitis $\mathrm{C}$ virus transmission to surgical and dental patients. J Viral Hepat. 2001;8(2):148-153.

38. Amer FA, Gohar M, Yousef M. Epidemiology of Hepatitis C Virus Infection in Egypt. International Journal of Tropical Disease \& Health. 2015;7(3):119-131.

39. Yuan JM, Govindarajan S, Arakawa K, et al. Synergism of alcohol, diabetes, and viral hepatitis on the risk of hepatocellular carcinoma in blacks and whites in the U.S. Cancer. 2004;101(5):1009-1017. 